\title{
Aldosterone decreases glucose-stimulated insulin secretion in vivo in mice and in murine islets
}

\author{
J. M. Luther • P. Luo • M. T. Kreger • M. Brissova • \\ C. Dai • T. T. Whitfield • H. S. Kim • D. H. Wasserman • \\ A. C. Powers • N. J. Brown
}

Received: 11 January 2011 /Accepted: 28 March 2011/Published online: 26 April 2011

(C) Springer-Verlag 2011

\begin{abstract}
Aims/hypothesis Aldosterone concentrations increase in obesity and predict the onset of diabetes. We investigated the effects of aldosterone on glucose homeostasis and insulin secretion in vivo and in vitro.

Methods We assessed insulin sensitivity and insulin secretion in aldosterone synthase-deficient (As [also known as $C y p 11 b 2]^{-/}$) and wild-type mice using euglycaemic-hyperinsulinaemic and hyperglycaemic clamps, respectively. We also conducted studies during high sodium intake to normalise renin activity and potassium
\end{abstract}

Electronic supplementary material The online version of this article (doi:10.1007/s00125-011-2158-9) contains supplementary material, which is available to authorised users.

J. M. Luther $(\varangle) \cdot$ P. Luo $\cdot$ M. T. Kreger $\cdot$ N. J. Brown

Department of Medicine, Division of Clinical Pharmacology,

Vanderbilt University Medical Center,

2200 Pierce Ave, 560 RRB,

Nashville, TN 37232-6602, USA

e-mail: James.Luther@Vanderbilt.edu

J. M. Luther

Department of Medicine, Division of Nephrology and

Hypertension, Vanderbilt University Medical Center,

Nashville, TN, USA

M. Brissova $\cdot$ C. Dai $\cdot$ A. C. Powers

Department of Medicine, Division of Diabetes, Endocrinology

and Metabolism, Vanderbilt University Medical Center,

Nashville, TN, USA

T. T. Whitfield

University of Tennessee School of Medicine,

Memphis, TN, USA

H. S. Kim

Department of Pathology and Laboratory Medicine,

University of North Carolina,

Chapel Hill, NC, USA concentration in $\mathrm{As}^{-/-}$mice. We subsequently assessed the effect of aldosterone on insulin secretion in vitro in the presence or absence of mineralocorticoid receptor antagonists in isolated $\mathrm{C} 57 \mathrm{BL} / 6 \mathrm{~J}$ islets and in the MIN6 beta cell line.

Results Fasting glucose concentrations were reduced in $\mathrm{As}^{-/-}$ mice compared with wild-type. During hyperglycaemic clamps, insulin and C-peptide concentrations increased to a greater extent in $\mathrm{As}^{-/-}$than in wild-type mice. This was not attributable to differences in potassium or angiotensin II, as glucose-stimulated insulin secretion was enhanced in $\mathrm{As}^{-/-}$

D. H. Wasserman • A. C. Powers

Department of Molecular Physiology and Biophysics,

Vanderbilt University Medical Center,

Nashville, TN, USA

D. H. Wasserman

NIH - Mouse Metabolic Phenotyping Center,

Vanderbilt University Medical Center,

Nashville, TN, USA

D. H. Wasserman • A. C. Powers

Diabetes Research Training Center,

Vanderbilt University Medical Center,

Nashville, TN, USA

A. C. Powers

VA Tennessee Valley Healthcare System,

Nashville, TN, USA 
mice even during high sodium intake. There was no difference in insulin sensitivity between $\mathrm{As}^{-/-}$and wildtype mice in euglycaemic-hyperinsulinaemic clamp studies. In islet and MIN6 beta cell studies, aldosterone inhibited glucose- and isobutylmethylxanthine-stimulated insulin secretion, an effect that was not blocked by mineralocorticoid receptor antagonism, but was prevented by the superoxide dismutase mimetic tempol.

Conclusions/interpretation We demonstrated that aldosterone deficiency or excess modulates insulin secretion in vivo and in vitro via reactive oxygen species and in a manner that is independent of mineralocorticoid receptors. These findings provide insight into the mechanism of glucose intolerance in conditions of relative aldosterone excess.

Keywords Aldosterone - Aldosterone synthase . Diabetes mellitus · Glucose clamp technique - Insulin . Mineralocorticoid receptor Pancreatic beta cells . Renin-angiotensin-aldosterone system

$\begin{array}{ll}\text { Abbreviations } \\ \text { ARB } & \text { Angiotensin receptor blocker } \\ \text { DREAM } & \begin{array}{l}\text { Diabetes Reduction Assessment with Ramipril } \\ \text { and Rosiglitazone Medication }\end{array} \\ \text { GTT } & \begin{array}{l}\text { Glucose tolerance test } \\ \text { IBMX }\end{array} \\ \text { Isobutylmethylxanthine } \\ \text { IEQ } & \text { Islet equivalent } \\ \text { MR } & \text { Mineralocorticoid receptor } \\ \text { RAAS } & \text { Renin-angiotensin-aldosterone system }\end{array}$

\section{Introduction}

Aldosterone classically stimulates sodium reabsorption in the distal nephron via the mineralocorticoid receptor (MR), although many extra-renal effects are now appreciated. Aldosterone contributes to myocardial fibrosis, nephrosclerosis and vascular injury even in the absence of severe hypertension [1]. Although the renin-angiotensin-aldosterone system (RAAS) is normally activated during conditions of low sodium or fluid intake, it may be inappropriately elevated in obese individuals. In particular, elevated aldosterone concentrations are associated with obesity and the metabolic syndrome [2-5]. This correlation may be due to the stimulation of aldosterone synthesis by oxidised fatty acids or other circulating aldosteronestimulatory factors, which act on the adrenal gland independently of angiotensin II [6]. This relationship has led investigators to implicate aldosterone in the development of diabetes, although a causal role has not been firmly established [7].
Aldosterone excess produces insulin resistance in animals and correlates with insulin resistance in humans $[8,9]$. Insulin resistance progresses to overt type 2 diabetes when pancreatic beta cells can no longer secrete sufficient insulin to maintain normoglycaemia [10]. The effect of aldosterone on insulin secretion has not been extensively studied; however, an inverse relation between insulin secretion and aldosterone tertiles was observed in a cross-sectional study of hypertensive patients, suggesting an effect of aldosterone on beta cell function [11]. Furthermore, blockade of the RAAS with either ACE inhibitors or angiotensin receptor blockers (ARBs) has beneficial effects on glucose homeostasis, but the mechanism remains uncertain $[12,13]$. Because ACE inhibitors or ARBs decrease aldosterone concentrations at least transiently, and the aldosterone and angiotensin pathways are interrelated, the beneficial effects of these drugs may be mediated by alterations in aldosterone signalling.

Aldosterone synthase is the primary enzyme responsible for production of aldosterone by conversion of corticosterone to aldosterone. Aldosterone synthase-deficient mice (As [also known as Cyp11b2 $]^{-/}$) are incapable of producing aldosterone and provide a tool to investigate the role of endogenous aldosterone in glucose metabolism [14, 15]. Using $\mathrm{As}^{-/-}$mice and glucose clamp techniques, we investigated the role of endogenous aldosterone in the regulation of insulin sensitivity and pancreatic beta cell function in mice. Because potassium and renin activity are increased in $\mathrm{As}^{-/-}$mice during normal sodium intake [14], we also performed studies during high sodium intake, which normalises these measures. We also explored the direct effects of aldosterone and MR antagonism in isolated wild-type murine islets and clonal beta cells.

\section{Methods}

Animals All experiments were approved by the Vanderbilt Institutional Animal Care and Use Committee. $\mathrm{As}^{-1-}$ mice were generated on a 129 background [16] and were backcrossed over $\geq 10$ generations on to the C57BL/6J strain obtained from Jackson Laboratory (Bar Harbor, ME, USA). Mice were genotyped as previously described [15]. We studied 12- to 16-week-old male mice. $A s^{-/-}$mice and their wild-type littermates had free access to standard mouse chow (Rodent 5001; Purina Laboratory, Richmond, IN, USA) and water, and were housed in a temperaturecontrolled facility with a $12 \mathrm{~h}$ light/dark cycle. During highsodium experiments, mice drank $0.9 \%$ saline (wt/vol.) for 1 week prior to study.

General clamp procedures A surgically implanted gastric feeding tube and carotid arterial catheter were implanted for 
glucose tolerance tests (GTTs). Carotid arterial and jugular venous catheters were implanted for euglycaemic and hyperglycaemic clamps 3-5 days prior to study and clamp protocols were conducted as previously described [17-19]. Basal samples were taken between $t=-15$ and $0 \mathrm{~min}$ in each clamp protocol after a $5 \mathrm{~h}$ fast, which started at 08:00 hours. During hyperglycaemic clamps, a variable glucose infusion rate was used to increase and maintain blood glucose at $13.9-16.7 \mathrm{mmol} / \mathrm{l}$ during the experimental period. Human insulin was used during hyperinsulinaemic clamps (Humulin R; Eli Lilly, Indianapolis, IN, USA).

Islet isolation, culture and perifusion Murine islets were isolated from 12- to 18-week-old C57BL/6 J male mice and islet perifusion performed as previously described [19]. Since steroids are present in FBS, which is typically used in islet culture, we performed all cultures and assessments of insulin secretion by isolated islets using steroid-free FBS (Sigma Aldrich, St Louis, MO, USA). Purified islets were cultured for $16-24 \mathrm{~h}$ and at $37^{\circ} \mathrm{C}$ in RPMI-1640 with $5.6 \mathrm{mmol} / \mathrm{l}$ glucose $+10 \%$ steroid-free FBS, in the presence or absence of aldosterone, spironolactone, eplerenone and tempol (all Sigma-Aldrich), and a combination of the treatments. After overnight culture, insulin secretion was assessed using static incubation or a cell perifusion system. Islets were matched for size and number, and assessed as islet equivalents (IEQ). Static incubation studies were performed for $30 \mathrm{~min}$ at $37^{\circ} \mathrm{C}$ in fresh $2 \mathrm{ml} \mathrm{RPMI}-1640$ containing $16.7 \mathrm{mmol} / \mathrm{l}$ glucose with or without treatment. Dynamic islet insulin secretion was evaluated in a cell perifusion apparatus consisting of four parallel columns, with insulin extracted as described previously [20].

Clonal beta cell culture and static insulin secretion studies MIN6 cells originally obtained from J. Miyazaki [21] were cultured in DMEM containing $25 \mathrm{mmol} / 1$ glucose with $10 \%$ steroid-free $\mathrm{FBS}, 100 \mathrm{~g} / \mathrm{ml}$ streptomycin, 100 units $/ \mathrm{ml}$ penicillin sulphate (Invitrogen, Carlsbad, CA, USA) and $70 \mu \mathrm{mol} / 1$ beta mercaptoethanol (Sigma). Cells used in these studies were maintained at passage 24-30. Upon reaching $80 \%$ confluence, cells were seeded into 24 well plates at $1 \times 10^{6}$ cells/well and maintained for 3-4 days. Fresh medium containing the indicated concentration of aldosterone, RU-28318 (Tocris Bioscience, Bristol, UK) or DMSO vehicle was added $12-16 \mathrm{~h}$ before studies. During static incubation, cells were pre-incubated for $2 \mathrm{~h}$ with KRB without glucose, then challenged for $1 \mathrm{~h}$ at $37^{\circ} \mathrm{C}$ with $500 \mu \mathrm{l}$ $\mathrm{KRB}$ containing 0 or $23 \mathrm{mmol} / \mathrm{l}$ glucose. Treatment or control drugs were present throughout static incubations. Insulin was measured using an ELISA kit (ALPCO, Salem, NH, USA).

Laboratory assays In all clamp protocols, arterial wholeblood glucose was measured using the glucose oxidase method
(Accu-Chek; Roche Diagnostics, Basel, Switzerland). Plasma collected during the clamp studies or fractions from the perifusion studies were used for insulin and C-peptide assays. Insulin and C-peptide concentrations were determined by RIA (Millipore, St. Charles, MO, USA). In a separate group of animals during normal and high sodium intake (10 wild-type, $12 \mathrm{As}^{-1-}$ ), blood was collected via the saphenous vein into heparin-coated tubes and immediately analysed for potassium (iSTAT EC8+ cartridge; Heska, Loveland, TX, USA). Pancreatic insulin content and islet area were determined as previously described [19].

Statistical analysis and calculations Data are presented as mean \pm SEM unless otherwise specified. For comparisons between genotype, Wilcoxon's signed-rank test and Wilcoxon's rank-sum test were used for paired and unpaired comparisons respectively. Repeated-measures ANOVA was used with post hoc least significant difference analysis to compare treatment effects between groups for plasma measurements. Islet perifusion and static culture results were analysed using ANOVA with study day as a covariate. All statistical analyses were performed using SPSS for Windows (version 17.0; SPSS, Chicago, IL, USA), with a two-tailed value of $p<0.05$ considered to be significant.

Additional details For other details on methods, see electronic supplementary material (ESM), Methods.

\section{Results}

Fasting blood glucose is reduced in $\mathrm{As}^{-/}$mice without alteration of glucose tolerance After a $5 \mathrm{~h}$ morning fast, arterial glucose was significantly lower in $\mathrm{As}^{-/-}$mice than in wild-type controls $(7.46 \pm 0.27$ vs $8.75 \pm 0.33 \mathrm{mmol} / \mathrm{l}, p=$ 0.003 ) (Fig. 1a). Insulin tended to be higher in $A s^{-/-}$mice (Fig. 1b). Because the circulating half-life of C-peptide is longer than that of insulin, we also assessed C-peptide concentrations. C-peptide was significantly increased in $A s^{-1-}$ mice (Fig. 1c). Body weight, fat mass and gonadal fat weight were similar in a separate set of age-matched wildtype and $\mathrm{As}^{-1-}$ mice (see ESM, Results).

To assess whether fasting glucose, gastrointestinal glucose absorption and incretin signalling were similar in $A s^{-/-}$and wild-type mice, we performed GTTs in wild-type $(n=7)$ and $A s^{-/-}(n=7)$ mice via a previously implanted percutaneous gastric feeding catheter, with blood sampling via arterial catheters. Whole-blood arterial glucose after a $5 \mathrm{~h}$ fast (08:00 to 13:00 hours) was higher in wild-type than in $A s^{-/-}$mice $(9.21 \pm 0.44$ vs $6.56 \pm 0.44 \mathrm{mmol} / \mathrm{l}$, respectively, $p=0.004)$ (Fig. 1d), while fasting plasma insulin concentrations were $33.0 \pm 7.7 \mathrm{pmol} / 1$ in wild-type and $17.1 \pm 3.8 \mathrm{pmol} / 1 \mathrm{in} A s^{-1-}$ mice $(p=0.09)$ (Fig. 1e). Glucose increased significantly in 

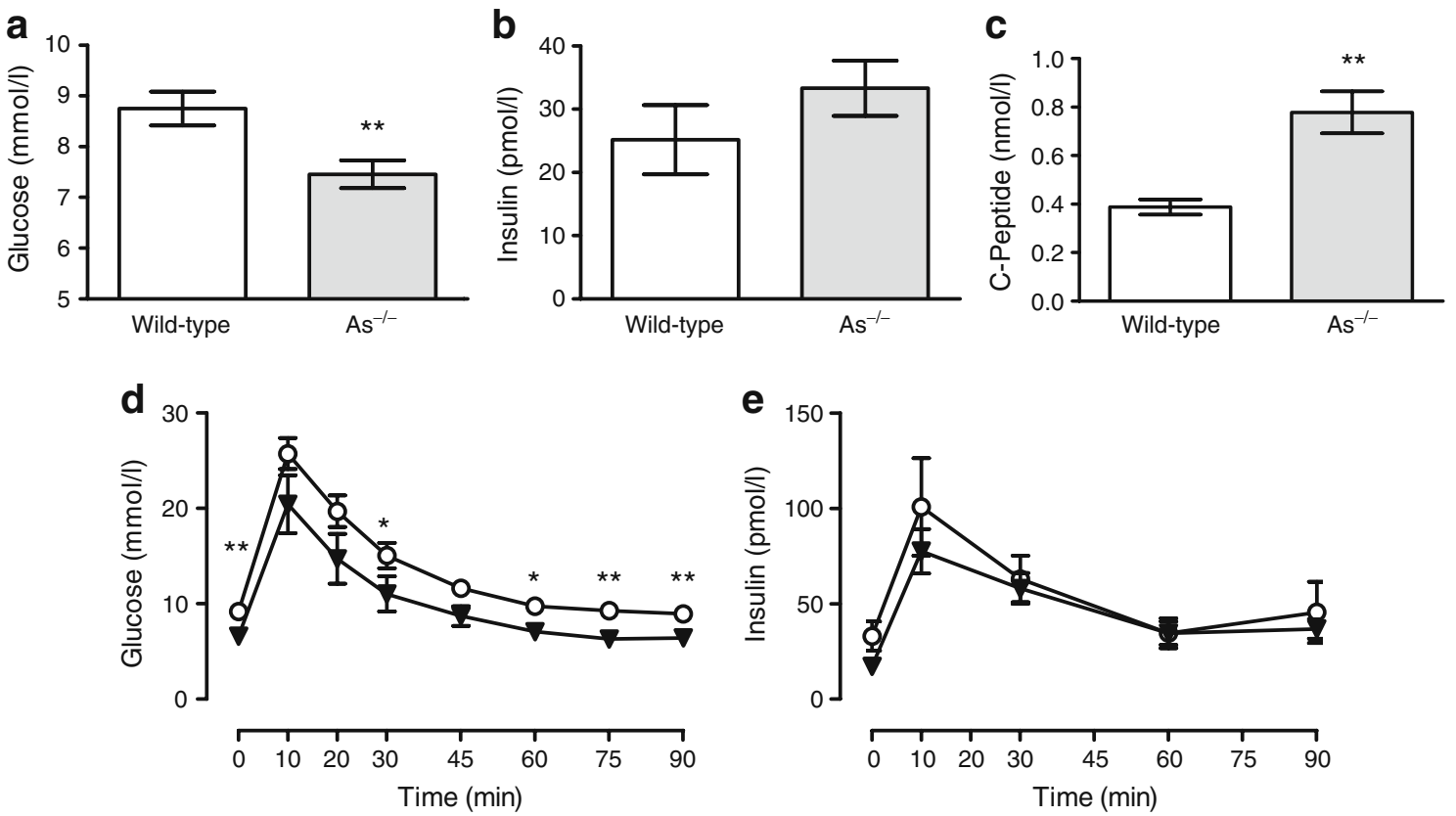

Fig. 1 Fasting glucose is lower and oral glucose tolerance is normal in $\mathrm{As}^{-1-}$ mice. a Data from pooled studies demonstrate that fasting plasma glucose was significantly lower in $\mathrm{As}^{-/-}$than in wild-type (WT) mice ( $n \geq 25$ per each genotype). Fasting insulin (b) tended to increase $(p=0.07, n \geq 25)$ and C-peptide (c) was significantly higher in

$A s^{-1-}$ mice $(n \geq 17)$. d During the GTTs, glucose was reduced in $A s^{-/-}$ (triangles) compared with wild-type (circles) mice, although the changes in glucose and baseline-corrected AUC glucose results were similar. e The baseline-corrected AUC insulin was also similar. ${ }^{*} p \leq$ $0.05,{ }^{*} p \leq 0.01$ between genotypes

both groups during the GTT, with peak values occurring at $10 \mathrm{~min}$ (Fig. 1d). Although glucose remained higher in wildtype mice, the magnitude of change in glucose was similar in wild-type and $A s^{-1-}$ mice $(16.6 \pm 1.39 \mathrm{vs} 13.83 \pm 2.78 \mathrm{mmol} / \mathrm{l}$, $p=0.75$ ). The area under the glucose-time curve, corrected for baseline glucose, was also similar between the two groups $(p=0.32)$. Likewise, the absolute increase in insulin was similar in each group (wild-type $66.7 \pm 26.1$ vs $60.9 \pm$ $14.5 \mathrm{pmol} / 1$ for $A s^{-/-}, p=0.95$ ) (Fig. 1e), despite higher glucose concentrations in wild-type mice.

Glucose-stimulated insulin secretion is increased in $\mathrm{As}^{-1-}$ mice independently of potassium concentration and RAAS activation To assess the effect of aldosterone deficiency on insulin secretion and to equalise confounding differences in glucose concentrations between wild-type and $A s^{-1-}$ mice, we conducted hyperglycaemic clamps in nine wild-type and nine $\mathrm{As}^{-/-}$mice aged 12 to 18 weeks. Intravenous glucose was infused at variable rates as necessary to maintain plasma glucose at similar steady-state levels (terminal $30 \mathrm{~min}$ of the study) in each genotype $(13.17 \pm 0.56$ vs $14.11 \pm 0.44 \mathrm{mmol} / 1$ in wild-type vs $A s^{-1-}$ mice, $p=0.22$ ) (Fig. 2a). Insulin concentrations during steady-state glucose were significantly higher in $A s^{-1-}$ mice than in wild-type controls $(47.9 \pm 4.64 \mathrm{vs}$ $89.9 \pm 11.3 \mathrm{pmol} / \mathrm{l}$ wild-type vs $A s^{-/-}, p=0.001$ ) (Fig. 2b). Cpeptide concentrations were also significantly higher in $\mathrm{As}^{-/-}$

mice, demonstrating that increased insulin concentrations in $\mathrm{As}^{-/-}$mice resulted from insulin secretion, rather than altered insulin metabolism $(p<0.01)$ (Fig. 2c). The terminal glucose infusion rate was similar in the two groups $\quad(1.45 \pm 0.43$ vs $\left.1.50 \pm 0.37 \mathrm{mmol} \mathrm{kg}^{-1} \mathrm{~min}^{-1}, p=0.67\right)$.

In mice ingesting a normal sodium diet, serum potassium was significantly higher in $A s^{--}$mice $(5.0 \pm 0.2$ vs $5.8 \pm$ $0.2 \mathrm{mmol} / \mathrm{l}$, wild-type vs $\left.A s^{-/-}, p=0.004\right)$. Because potassium stimulates insulin secretion, and high sodium intake normalises serum potassium and renin activity in $\mathrm{As}^{-/}$ mice [16], we repeated hyperglycaemic clamps in mice during high sodium intake (five wild-type, four $\mathrm{As}^{-1}$ ). During high sodium intake $(0.9 \%$ saline drinking for 5 7 days), potassium in $\mathrm{As}^{-1-}$ mice was similar to that of wildtype, $\left(5.2 \pm 0.2\right.$ vs $5.3 \pm 0.2 \mathrm{mmol} / \mathrm{l}$, wild-type vs $A s^{-/-}, p=$ 0.88 ). Glucose concentration was similar at steady state (13.83 \pm 0.56 vs $13.33 \pm 0.56 \mathrm{mmol} / \mathrm{l}$, wild-type vs $A s^{-1-}$, $p=0.73$ ) (Fig. 2d), while insulin (47.0 \pm 6.4 vs $127.6 \pm 9.3$ pmol/1, wild-type vs $A s^{-1-}, p=0.016$ ) (Fig. 2e) and Cpeptide $\left(514 \pm 50\right.$ vs $966 \pm 121 \mathrm{pmol} / \mathrm{l}$, wild-type vs $\mathrm{As}^{-/-}$, $p=0.001$ ) (Fig. 2f) were again significantly higher in $\mathrm{As}^{-/-}$ mice. The terminal glucose infusion rate required to maintain equivalent serum glucose concentrations was significantly higher in the $A s^{-/-}$than in the wild-type group ( $3.26 \pm 0.076$ vs $1.17 \pm 0.073 \mathrm{mmol} \mathrm{kg}{ }^{-1} \mathrm{~min}^{-1}, p=0.016$ ), reflecting the increased insulin concentration. 
Fig. 2 Glucose-stimulated insulin secretion is increased in $\mathrm{As}^{-/-}$mice. During hyperglycaemic clamp studies under normal sodium $(\mathbf{a}-\mathbf{c})$ and high sodium (d-f) conditions, glucose was infused to achieve equivalent glucose values at the terminal phase of the study. Terminal glucose (a, d) was similar in $\mathrm{As}^{-/-}$(triangles) compared with wild-type (circles) mice. Insulin $(\mathbf{b}, \mathbf{e})$ and $\mathrm{C}$ peptide $(\mathbf{c}, \mathbf{f})$ concentrations were significantly greater in $A s^{-/-}$than in wild-type mice. ${ }^{*} p \leq 0.05,{ }^{* *} p \leq 0.01$ and $* * * p \leq 0.001$ vs wild-type a

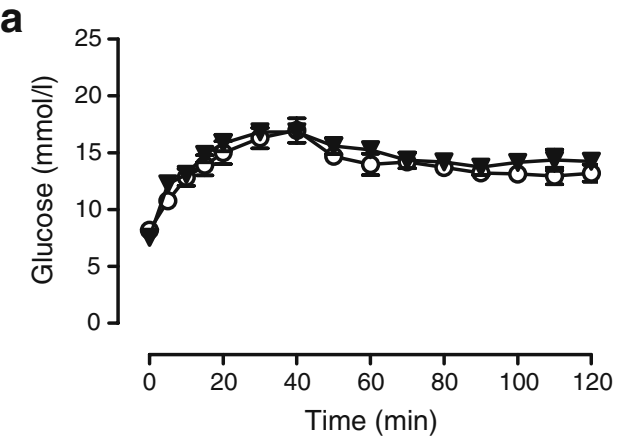

b
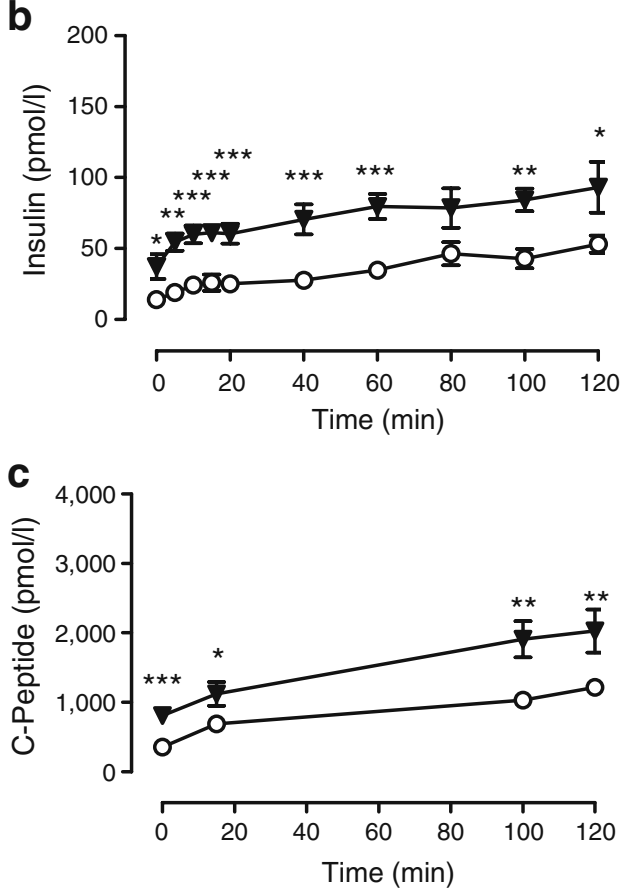

d

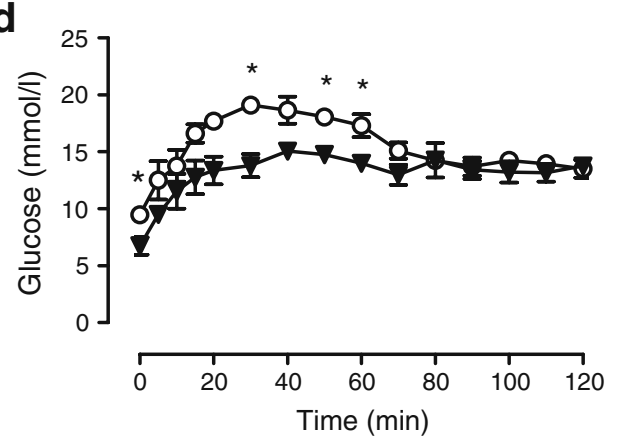

e
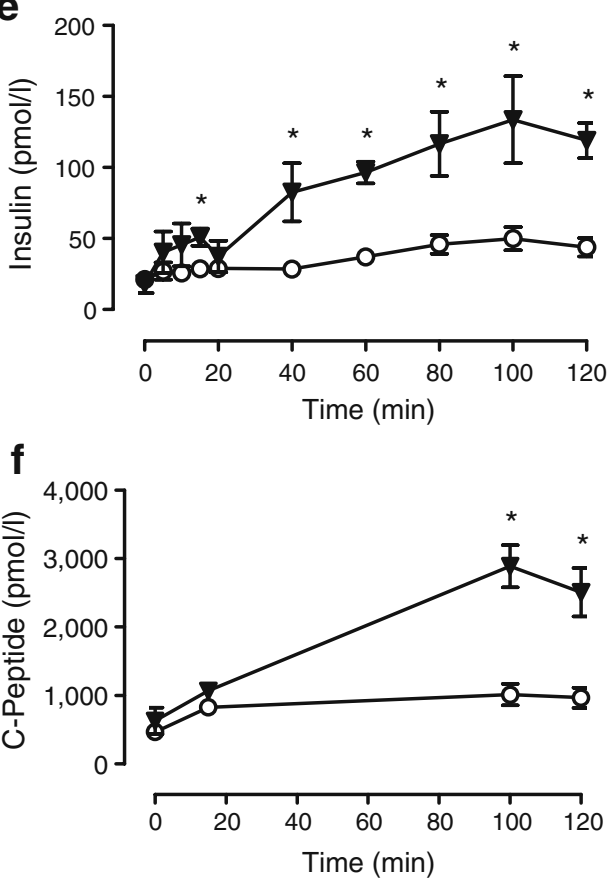

Pancreatic islet density and insulin content are unaltered in $\mathrm{As}^{-1-}$ mice To determine whether increased glucosemediated insulin secretion resulted from increased beta cell mass, we assessed pancreatic insulin content and conducted quantitative morphometric analysis of pancreatic tissue from $A s^{-/-}$and wild-type mice. Pancreatic insulin content was similar in both groups (132.7 \pm 11.7 and $149.8 \pm$ $13.9 \mathrm{nmol} / \mathrm{g}$ tissue, wild-type [ $n=5]$ and $A s^{-/-}[n=4], p=$ 0.56 ). Likewise, pancreatic islet area was similar between the two groups $(0.46 \pm 0.08$ vs $0.50 \pm 0.10 \%$ of total pancreas area, $n=5$ each group, $p=0.92$ ).

Aldosterone impairs insulin secretion in isolated murine islets and MIN6 beta cells To further exclude confounding by systemic effects of aldosterone and to better assess the direct effect of aldosterone on pancreatic islet cell function, we conducted studies in isolated wild-type murine islets. In a dose-ranging study, islets were cultured for $24 \mathrm{~h}$ in the presence of aldosterone and then stimulated with $16.7 \mathrm{mmol} / 1$ glucose in static culture for $30 \mathrm{~min}$ on the following day ( $n \geq 5$ replicates each group). Aldosterone impaired glucose-stimulated insulin response in a dosedependent manner (Fig. 3a). Islet insulin content, assessed after study completion, did not differ between treatment groups $(p=0.37)$ (Fig. 3a). Because the results were not affected by normalisation for islet insulin content, these studies suggest that aldosterone affects glucose sensing or stimulus-response coupling, rather than insulin production. Similar results were obtained in the MIN6 beta cell line during static culture, with maximal inhibition achieved between 10 and $100 \mathrm{nmol} / \mathrm{l}$ concentration (Fig. 3b). Under unstimulated conditions ( $0 \mathrm{mmol} / \mathrm{l}$ glucose in MIN6), $100 \mathrm{nmol} / 1$ aldosterone slightly decreased insulin secretion $(p=0.03)$.

We performed perifusion studies of isolated islets using aldosterone at concentrations of 10 and $1,000 \mathrm{nmol} / 1$ after overnight culture (Fig. 3c, d). Aldosterone decreased glucose- and isobutylmethylxanthine (IBMX)-stimulated insulin secretion in a dose-dependent manner (Fig. 3d, e), with a significant effect of $10 \mathrm{nmol} / \mathrm{l}$ aldosterone evident during peak IBMX stimulation (ESM Fig. 1) and a trend 
a

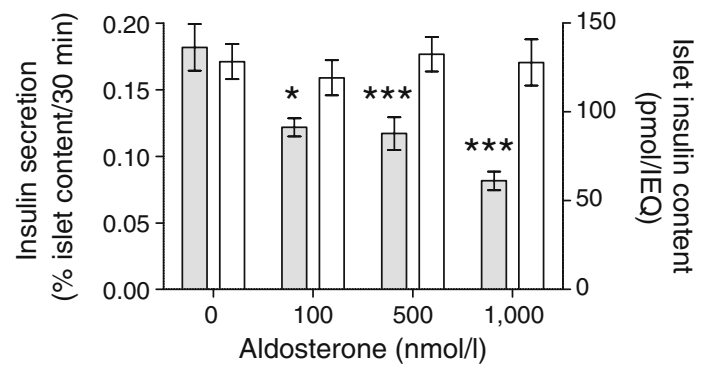

C
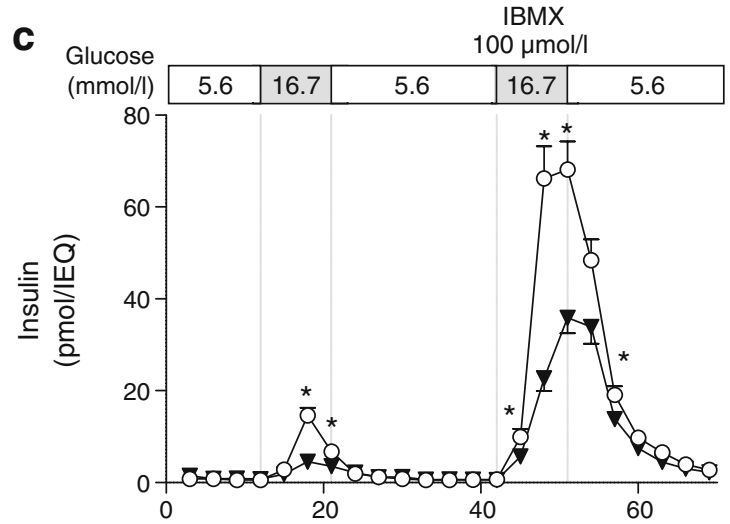

b

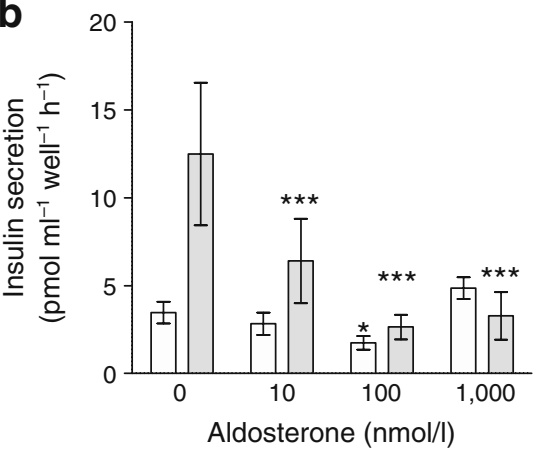

d
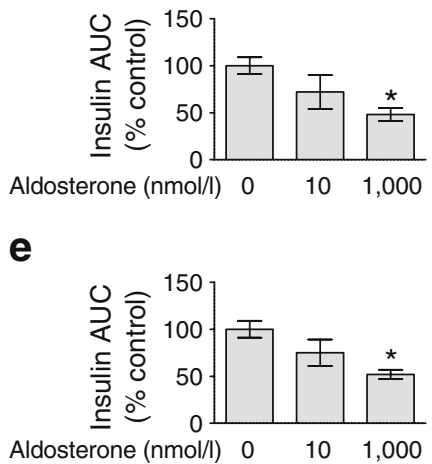

Fig. 3 Aldosterone decreases insulin secretion in a dose-dependent manner in isolated islets and the MIN6 beta cell line. a Aldosterone reduced glucose-stimulated insulin concentrations, assessed as insulin secreted after $16.7 \mathrm{mmol} / 1$ glucose stimulus for $30 \mathrm{~min}$ in static culture (grey bars). Total islet insulin content was unaltered by aldosterone (white bars), suggesting an effect on insulin secretion rather than insulin content. b In MIN6 cells, aldosterone decreased insulin secretion in response to $23 \mathrm{mmol} / \mathrm{l}$ glucose (grey bars), reaching maximal inhibition at $100 \mathrm{nmol} / 1 . \mathbf{c}$ In isolated islet perifusion studies, insulin secretion in response to glucose $(16.7 \mathrm{mmol} / \mathrm{l})$ and isobutylmethylxanthine (IBMX; $100 \mu \mathrm{mol} / \mathrm{l})$ was diminished in the presence of aldosterone $1000 \mathrm{nmol} / \mathrm{l}$ (triangles) compared with control (circles). d Insulin secretion quantified as insulin AUC was significantly lower in islets treated with aldosterone $(1000 \mathrm{nmol} / \mathrm{l})$ in response to glucose $(16.7 \mathrm{mmol} / \mathrm{l})$ and $(\mathbf{e})$ to glucose $(16.7 \mathrm{mmol} / \mathrm{l})+\operatorname{IBMX}(100 \mu \mathrm{mol} / \mathrm{l})$. $* p \leq 0.05$ and $* * * p \leq 0.001$ vs $0 \mathrm{nmol} / 1$ aldosterone towards significance during peak glucose stimulation $(p=$ 0.06). Aldosterone also impaired tolbutamide-induced insulin secretion $\left(10.5 \pm 0.9\right.$ vs $15.8 \pm 1.7 \mathrm{pmol} \mathrm{min}^{-1}$ $\mathrm{IEQ}^{-1}$ in the presence and absence of aldosterone, respectively, $p<0.01$ ). Aldosterone did not affect insulin secretion during the baseline period $(5.5 \mathrm{mmol} / \mathrm{l}$ glucose $)$.

Aldosterone impairs insulin secretion in an MR-independent manner We tested the effect of the specific MR antagonist eplerenone at $10 \mu \mathrm{mol} / \mathrm{l}$, a concentration greater than the established $\mathrm{IC}_{50}$ of $360 \mathrm{nmol} / 1$ [22, 23], on insulin secretion in perifused islets. Aldosterone significantly decreased insulin secretion in response to glucose and IBMX. Eplerenone alone did not affect insulin secretion or insulin content, or prevent the effect of aldosterone in perifused islets. Results were similar in response to glucose and IBMX (ESM Fig. 2a, b). We also tested a higher molar ratio of eplerenone to aldosterone by lowering the aldosterone concentration in isolated islet static culture: results were similar, suggesting that inadequate competition alone could not explain these results
(Fig. 4a). Results were similar during spironolactone treatment (ESM Fig. 2c, d). In MIN6 cells, the watersoluble MR antagonist RU-28318 (10 $\mu \mathrm{mol} / \mathrm{l})$ alone reduced insulin secretion and did not prevent the effect of aldosterone (Fig. 4b). Furthermore, MR protein abundance was markedly lower in MIN6 cells than in renal cortex (Fig. 4c). Glucocorticoid receptor antagonism with mifepristone $(10 \mu \mathrm{mol} / \mathrm{l})$ did not prevent the effect of aldosterone within isolated islets. However, pretreatment with the superoxide dismutase mimetic, tempol, prevented the effect of aldosterone on insulin secretion (Fig. 4d). These studies suggest that aldosterone alters insulin secretion in pancreatic islets and clonal beta cells via a mechanism that is independent of MR and glucocorticoid receptor, and involves generation of reactive oxygen species.

Mr mRNA is expressed in murine pancreatic islets To determine whether the MR is expressed in pancreatic islets, we assessed relative mRNA concentrations in pancreatic islets $(n=4)$ and MIN6 cells $(n=3)$, compared with renal cortex $(n=4)$ from wild-type mice (Table 1). Mr (also 
Fig. 4 Aldosterone impairs insulin secretion via an MRindependent mechanism and oxidative stress. a Eplerenone (EPL) did not prevent the effect of aldosterone (Aldo) on insulin secretion in isolated islet static culture. b The water-soluble MR antagonist RU-28318 did not prevent the effect of aldosterone in the clonal MIN6 cell line ( $0 \mathrm{mmol} / \mathrm{l}$ glucose, white bars; $23 \mathrm{mmol} / 1$ glucose, grey bars). c MR protein abundance was markedly reduced in MIN6 cells compared with renal cortex. d The antioxidant tempol prevented the effect of aldosterone in isolated islet studies. ${ }^{*} p<0.05$ and $* * p \leq 0.01$ vs control
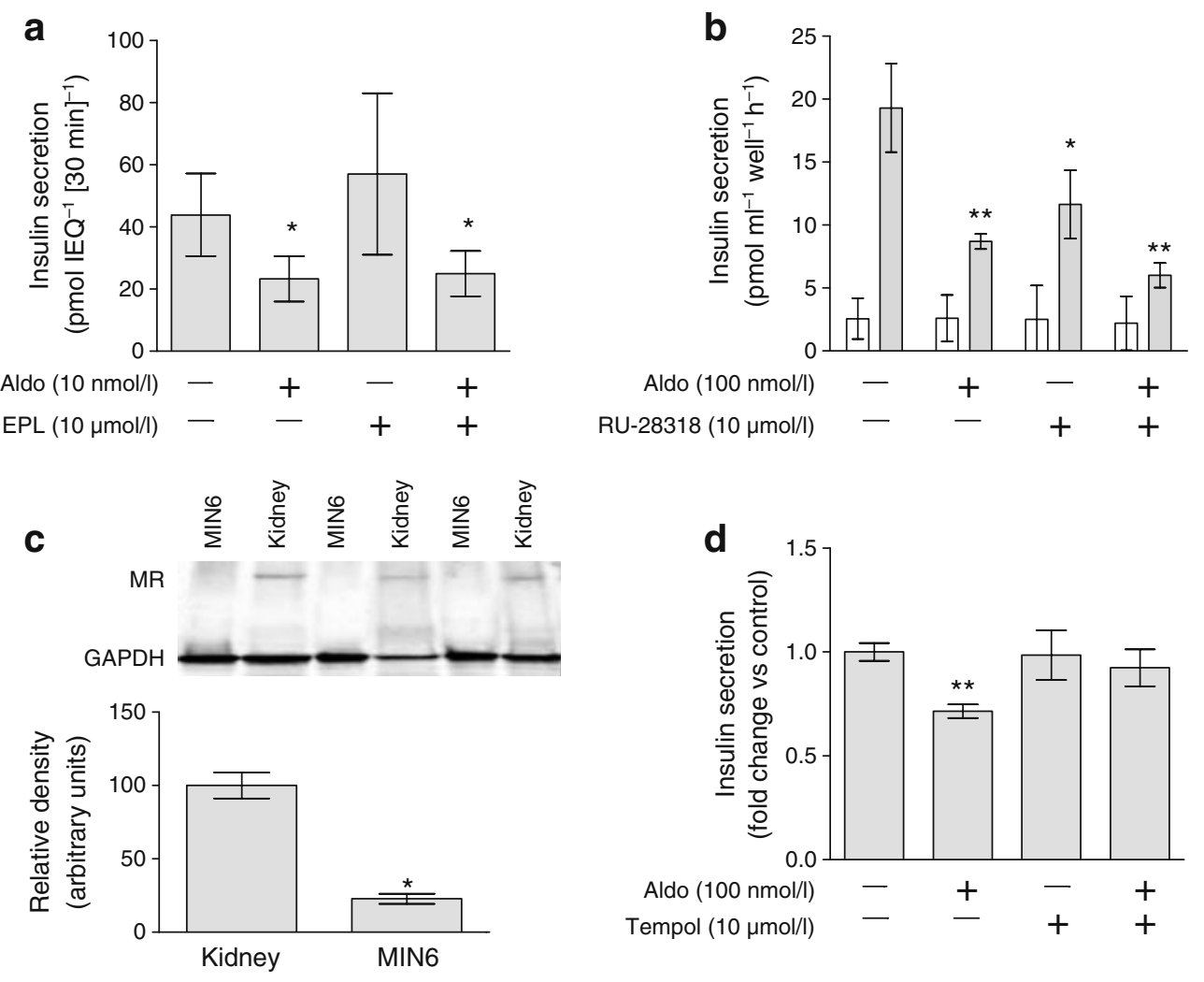

known as $\mathrm{Nr} 3 \mathrm{c} 2$ ) gene expression in isolated murine islets was similar to that in the renal cortex, with a trend towards being reduced in MIN6 cells. When compared within pancreatic islets, $M r$ mRNA was expressed at a much lower level than the beta cell-specific transcription factor Mafa (Table 2). Because 11beta-hydroxysteroid dehydrogenase types I and II affect the ability of glucocorticoids to activate the MR, we also assessed $11 \beta H s d 1$ and $11 \beta H s d 2$ (also known as $H s d 11 b 1$ and $H s d 11 b 2$, respectively) mRNA concentration. mRNA of $11 \beta H s d 1$ and $11 \beta H s d 2$ was detectable at much lower levels in the pancreatic islets and MIN6 cell line than with the respective concentrations in kidney (fold change $p \leq 0.02$ for each) (Table 1).

We performed immunohistochemistry on pancreatic islet sections to localise the MR, using a monoclonal antibody targeting the MR N-terminal amino acids 1-18 [24]. The MR co-localised with somatostatin- and pancreatic polypeptide-containing cells at the periphery of the islets
(Fig. 5). However, the MR did not co-localise with insulin or glucagon. Because the pancreatic islet is a highly vascularised structure, we also stained for the blood vessel endothelial marker CD31, but found no co-localisation (ESM Fig. 3).

Insulin sensitivity is unchanged in $\mathrm{As}^{-/-}$mice To determine whether endogenous aldosterone affects insulin sensitivity, we performed euglycaemic-hyperinsulinaemic clamps in three wild-type and six $A s^{-/-}$mice. Insulin (4 $\left.\mathrm{mU} \mathrm{kg}^{-1} \mathrm{~min}^{-1}\right)$ and glucose (variable rate) were infused intravenously to normalise glucose concentrations and the glucose infusion rate at the terminal portion of the study was used as an estimate of insulin sensitivity. Glucose concentrations during steady state (i.e. the terminal $30 \mathrm{~min}$ of the study) were maintained at $7.33 \pm$ $0.58 \mathrm{mmol} / \mathrm{l}$ in wild-type and $6.64 \pm 0.35 \mathrm{mmol} / 1$ in $A s^{-1-}$ mice $(p=0.26)$ (Fig. 6a). The average terminal glucose infusion

Table 1 Relative mRNA expression

\begin{tabular}{llrr}
\hline Tissue & $M r$ & $11 \beta H s d 1$ & $11 \beta H s d 2$ \\
\hline Renal cortex & $1.01 \pm 0.09$ & $1.00 \pm 0.06$ & $1.03 \pm 0.10$ \\
Pancreatic islets & $1.12 \pm 0.19$ & $0.02 \pm 0.007^{* * *}$ & $0.002 \pm 0.0006^{* * *}$ \\
MIN6 cell line & $0.68 \pm 0.08^{\dagger}$ & $0.0033 \pm 0.001^{* *}$ & $0.0067 \pm 0.001^{* * *}$ \\
\hline
\end{tabular}

Data are expressed as mean \pm SEM fold-changes vs renal cortex in each gene of interest; $18 \mathrm{~S}$ was used as endogenous control

${ }^{* *} p<0.01$ and $* * * p<0.001$ vs renal cortex; ${ }^{\dagger} p=0.07$ vs pancreatic islets 
Table 2 Relative mRNA expression in pancreatic islets

\begin{tabular}{lllll}
\hline Variable & Mafa & $M r$ & $11 \beta H s d 1$ & $11 \beta H s d 2$ \\
\hline Relative expression & $1.03 \pm 0.15$ & $0.15 \pm 0.02^{* * *}$ & $0.06 \pm 0.02 * * *$ & $0.01 \pm 0.002^{* * *}$ \\
\hline
\end{tabular}

Data are expressed as mean \pm SEM fold-changes vs Mafa for each gene of interest; $18 \mathrm{~S}$ was used as endogenous control *** $p<0.001$ vs Mafa

rate was similar in both groups $(0.240 \pm 0.016$ vs $0.222 \pm$ $0.021 \mathrm{mmol} \mathrm{kg} \mathrm{min}^{-1}$, wild-type vs $A s^{-1-}, p=0.71$ ) (Fig. 6c). Insulin concentrations were also statistically similar at steady state $(67.47 \pm 8.4$ vs $80.9 \pm 12.3 \mathrm{pmol} / \mathrm{l}$, wild-type vs $A s^{-/-}$, respectively, $p=0.79$ ). Tissue-specific glucose uptake, determined from the accumulation of 2deoxy- $\left[{ }^{14} \mathrm{C}\right]$ glucose phosphate in tissue (brain, adipose and muscle) from 2-deoxy- $\left[{ }^{14} \mathrm{C}\right]$ glucose injected intravenously during the clamp, was similar in the two genotype groups, with the exception of adipose tissue (Table 3), indicating that overall insulin action was similar in both mouse groups. Euglycaemic-hyperinsulinaemic clamps were also performed during high sodium intake in order to suppress endogenous aldosterone in wild-type mice and to control for alterations of potassium and angiotensin in $\mathrm{As}^{-1-}$ mice. Insulin sensitivity was unchanged by sodium intake and was similar among groups. No differences in tissue-specific glucose uptake or endogenous glucose production were observed (Fig. 6b, d, Table 3).

\section{Discussion}

The present study demonstrates that aldosterone deficiency enhances glucose-stimulated insulin secretion in vivo and that this effect is independent of electrolyte disturbance, insulin sensitivity or renin activity in $\mathrm{As}^{-/-}$ mice. Excess aldosterone, at a concentration consistent with that seen in primary aldosteronism and the metabolic syndrome, reduced insulin secretion in isolated perifused murine islets and in clonal beta cells through a mechanism that is independent of MR. To our
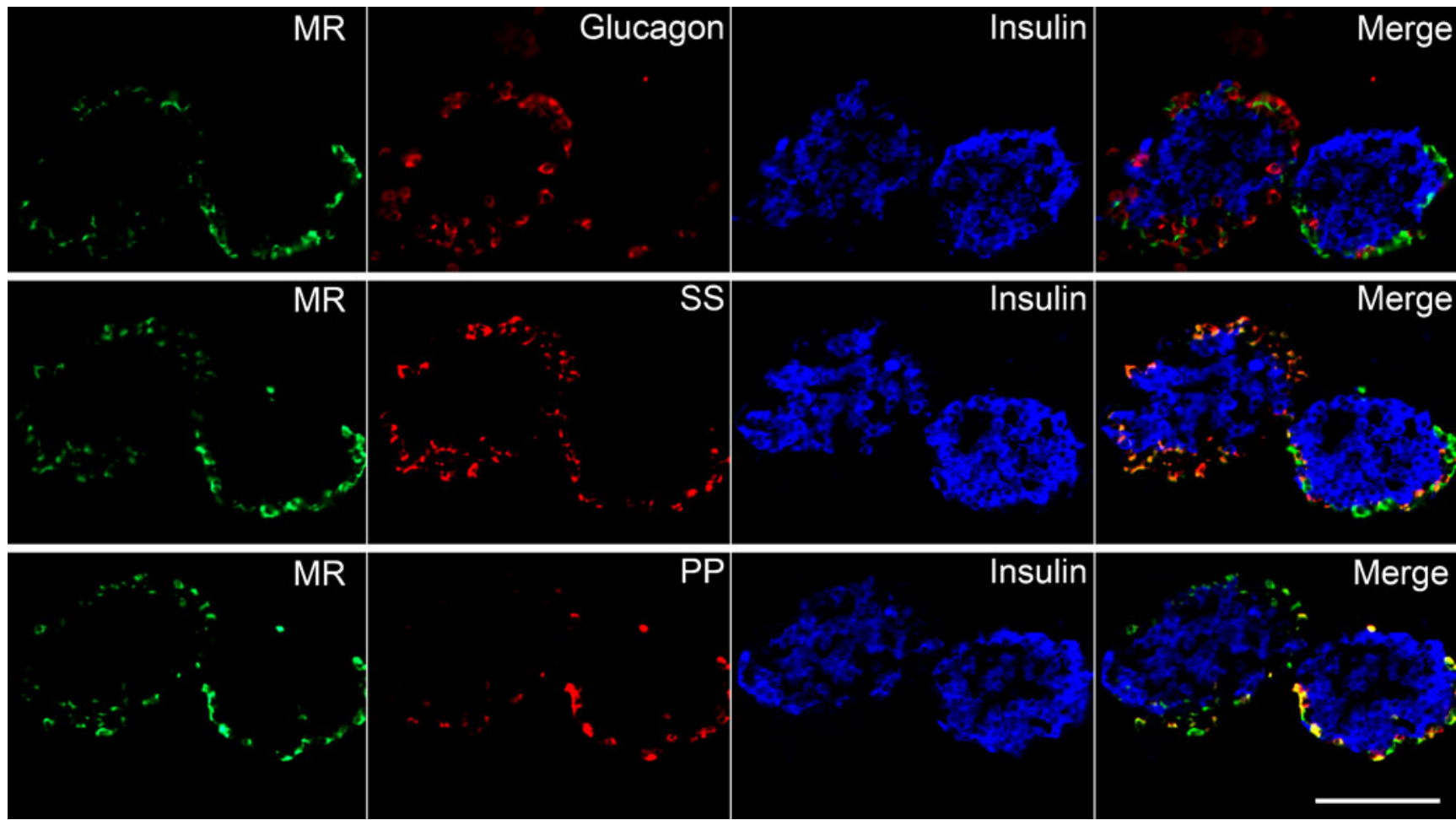

Fig. 5 The MR is produced in pancreatic delta and pancreatic polypeptide-positive cells in isolated murine islets. Immunofluorescence staining was performed on three consecutive sections of isolated murine islets embedded in collagen $(40 \times$ objective). The MR (green)

localised to the islet periphery and did not co-localise with insulin (blue pseudocolour) or glucagon (red, top row). The MR also colocalised with somatostatin- (SS, red, middle row) and pancreatic polypeptide-positive (PP) cells (red, bottom row). Scale bar $100 \mu \mathrm{m}$ 
Fig. 6 Insulin sensitivity is similar in wild-type and $\mathrm{As}^{-/}$ mice. Blood glucose $(\mathbf{a}, \mathbf{b})$ and glucose infusion rate $(\mathbf{c}, \mathbf{d})$ during euglycaemic-hyperinsulinaemic clamp studies in wild-type (circles) and $\mathrm{As}^{-/-}$ (triangles) mice while under normal (a, c) and high sodium intake (b, d). ${ }^{*} p \leq 0.05$ vs wild-type
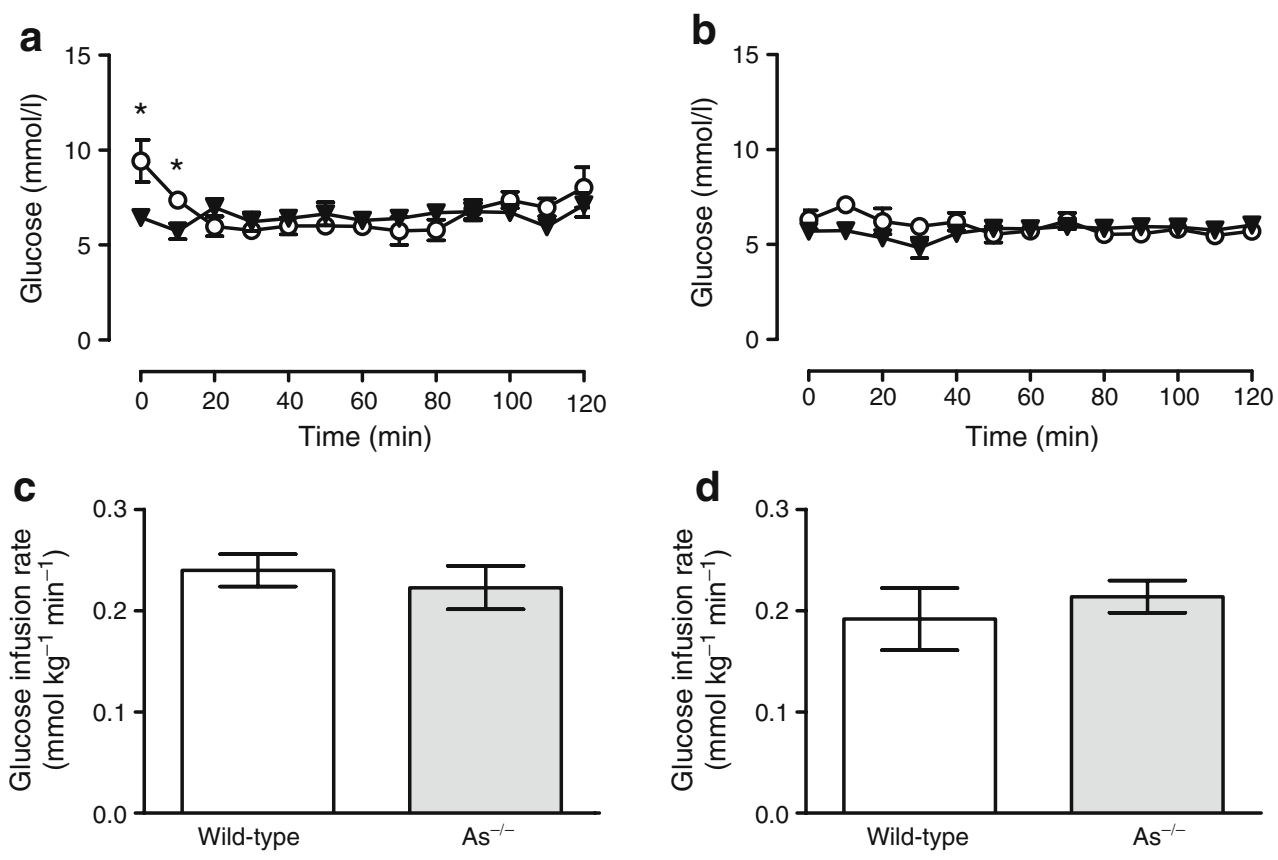

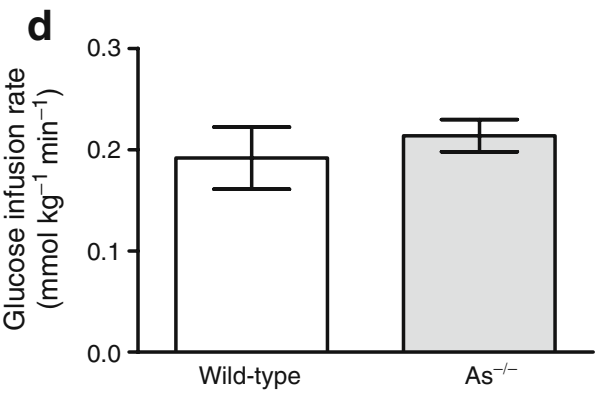

knowledge, this is the first study to demonstrate that endogenous aldosterone regulates insulin secretion and that perturbation of aldosterone directly alters insulin secretion within beta cells.

Mouse and rat models harbouring renin transgenes exhibit altered glucose homeostasis [25, 26]. Supraphysiological concentrations of angiotensin II and aldosterone impair insulin sensitivity in skeletal muscle of rodents $[27,28]$. Recent studies demonstrating the presence of RAAS components in pancreatic islets suggest that renin or angiotensin II also play a physiological role in insulin secretion [29, 30]. Clinical studies in humans suggest that interruption of the RAAS may reduce diabetes risk [31]. The ARB valsartan prevented progression to diabetes in participants with impaired glucose tolerance [13]. In the Diabetes Reduction Assessment with Ramipril and Rosiglitazone Medication (DREAM) trial, the ACE inhibitor ramipril improved the incidence of normoglycaemia, but not the development of diabetes [12]. Because previous observational studies of the effect of RAAS blockade on diabetes risk have been performed in patients with congestive heart failure and during diuretic use, lack of diuretic-induced RAAS activation in the DREAM trial may have diminished the effect of ramipril [31].

Most human studies on the effect of hyperaldosteronism have focused on insulin sensitivity, while none has assessed insulin secretion using hyperglycaemic clamps. Sindelka et al. demonstrated that surgical removal, but not spironolactone treatment, improved insulin sensitivity in patients with aldosterone-producing adenomas [32]. Other studies have yielded mixed findings in patients with primary aldosteronism [32, 33]. Furthermore, studies that have estimated insulin sensitivity by HOMA may be confounded by differences in insulin secretion [34].
Table 3 Endogenous glucose production and tissue-specific glucose uptake during euglycaemic-hyperinsulinaemic clamp during normal and high sodium intake

Data are expressed as mean \pm SEM

Endo $R$ was not assessed during normal sodium

Endo $R_{\mathrm{a}}$, endogenous glucose production; $R_{\mathrm{g}}$, glucose uptake $* p<0.05$ vs wild-type

\begin{tabular}{|c|c|c|c|c|}
\hline \multirow[t]{2}{*}{ Variable } & \multicolumn{2}{|c|}{ Normal sodium } & \multicolumn{2}{|l|}{ High sodium } \\
\hline & $\begin{array}{l}\text { Wild-type } \\
n=3\end{array}$ & $\begin{array}{l}A s^{-/-} \\
n=6\end{array}$ & $\begin{array}{l}\text { Wild-type } \\
n=4\end{array}$ & $\begin{array}{l}A s^{-/-} \\
n=10\end{array}$ \\
\hline Endo $R_{\mathrm{a}}\left(\mathrm{mg} \mathrm{kg}^{-1} \mathrm{~min}^{-1}\right)$ & NA & NA & $15.4 \pm 2.0$ & $15.1 \pm 0.9$ \\
\hline \multicolumn{5}{|c|}{ Tissue $R_{\mathrm{g}}\left(\mu \mathrm{g} \min ^{-1}[\mathrm{mg} \text { tissue }]^{-1}\right)$} \\
\hline Gastrocnemius & $14.6 \pm 2.1$ & $9.4 \pm 2.2$ & $16.5 \pm 4.8$ & $12.8 \pm 2.2$ \\
\hline Vastus lateralis & $14.0 \pm 2.3$ & $8.7 \pm 2.1$ & $14.3 \pm 2.2$ & $10.9 \pm 1.9$ \\
\hline Soleus & $79.8 \pm 19.7$ & $54.4 \pm 15.2$ & $85.3 \pm 24.2$ & $46.0 \pm 8.4$ \\
\hline Diaphragm & $133.7 \pm 43.8$ & $152.9 \pm 15.0$ & $107.3 \pm 20.0$ & $80.9 \pm 15.3$ \\
\hline Heart & $394.1 \pm 45.3$ & $349.5 \pm 40.2$ & $239.3 \pm 68.7$ & $206.2 \pm 29.9$ \\
\hline Adipose & $3.35 \pm 1.0$ & $9.06 \pm 1.9^{*}$ & $6.3 \pm 1.8$ & $5.9 \pm 1.0$ \\
\hline Brain & $60.6 \pm 8.7$ & $49.1 \pm 3.0$ & $53.7 \pm 11.9$ & $38.6 \pm 4.8$ \\
\hline
\end{tabular}


To date, few studies have addressed the effects of aldosterone on insulin secretion in pancreatic islets. Pierluissi et al. mentioned that aldosterone $(8 \mathrm{nmol} / \mathrm{l})$ reduced insulin secretion by $18 \%$ in isolated rat islets compared with controls, but did not assess the effect of aldosterone on the beta cell, the dose-response or the effect of MR antagonism [35]. Our studies expand substantially on these preliminary findings, providing direct evidence that aldosterone affects insulin secretion in vivo and in vitro, and demonstrating that this effect is independent of MR and the glucocorticoid receptor, and is mediated via production of reactive oxygen species. Moreover, studies in the MIN6 cell line suggest that aldosterone exerts this effect directly within beta cells.

In vivo, aldosterone synthase deficiency could affect insulin secretion due to indirect effects of increased angiotensin II or potassium. During normal sodium intake, relative volume depletion and increased angiotensin II in $\mathrm{As}^{-/-}$mice would be expected to decrease islet blood flow and insulin secretion. However, potassium is also elevated under these conditions in $\mathrm{As}^{-/-}$mice and directly stimulates insulin secretion in isolated islets. We controlled for these possible confounders in two ways. First, we studied $A s^{-/-}$mice treated with a high sodium diet, which reduces plasma renin activity, angiotensin II and plasma potassium [14]. In this setting, we found that glucose-stimulated insulin secretion was enhanced further in $\mathrm{As}^{-/-}$mice, even though potassium and plasma renin activity were comparable in wild-type and $\mathrm{As}^{-/-}$ mice under these conditions. Second, aldosterone reduced insulin secretion in isolated perifused islets and MIN6 cells, during which potassium concentration and perfusion pressure were held constant. Although circulating glucocorticoids could affect insulin secretion in $\mathrm{As}^{-/-}$mice, we have previously determined that corticosterone is unchanged compared with wild-type littermates [15]. In addition, we used steroid-free culture media during the in vitro studies specifically to avoid the confounding effect of glucocorticoids.

To assess the contribution of the MR to effects of aldosterone on insulin secretion, we examined the abundance and localisation of the MR within pancreatic islets. Chuang et al. have characterised the nuclear hormone receptor mRNA profile in islets and demonstrated expression of $M R$ mRNA within isolated murine and human islets [36]. We also found that $M r$ mRNA is expressed in pancreatic islets, and localised to a subset of cells in the islet periphery (delta and pancreatic polypeptide cells), rather than to beta cells. The effect of aldosterone on insulin secretion in cultured MIN6 cells demonstrates that aldosterone exerts a direct effect on beta cells, while the low abundance of MR protein in beta cells also suggests an MR-independent mechanism. Our pharmacological studies also confirm that aldosterone regulates insulin secretion via an MR-independent mechanism.
Specifically, the MR antagonists spironolactone, eplerenone and RU-28318 did not prevent inhibition of insulin secretion by aldosterone, suggesting that aldosterone affects insulin secretion via an MR-independent mechanism. The classic aldosterone signalling pathway within the principal cells of the kidney involves MR activation, homodimerisation, translocation to the nucleus and increased transcription of target genes. However, aldosterone may also exert non-genomic and MR-independent effects in non-epithelial tissues such as the vasculature, cardiomyocytes and other tissues [37]. The non-genomic effects of aldosterone do not involve DNA transcription, and in some cases are not blocked by MR antagonists [37-41]. The finding that aldosterone attenuated insulin secretion in response to glucose, IBMX and the sulfonylurea tolbutamide suggests that aldosterone exerted an effect downstream from $\mathrm{K}_{\text {ATP. }}$ Moreover, our data suggest that aldosterone impairs insulin secretion by increasing the production of reactive oxygen species. Aldosterone is known to induce oxidative stress in other settings [42], and reactive oxygen species impair insulin secretion [43].

The finding that aldosterone impairs insulin secretion in vitro and in vivo may have broad implications for patients with insulin resistance and impaired glucose tolerance, because impaired beta cell function is a necessary step in progression to type 2 diabetes [10]. Since plasma aldosterone concentrations are inappropriately elevated in obesity [2], aldosterone may be a critical link between obesity and the insulin resistance and impaired insulin secretion that produce overt diabetes. Although previous studies have demonstrated that aldosterone and the MR promote adipocyte differentiation in vitro [44], $\mathrm{As}^{-1-}$ mice exhibited no difference in adiposity measures, suggesting that aldosterone deficiency alone may not reduce adipose mass. Rather, it appears that fatderived factors promote aldosterone secretion in the setting of obesity and the metabolic syndrome [6]. We therefore hypothesise that aldosterone could further contribute to diabetes progression by impairing the insulin secretory response. Interestingly, insulin secretion was impaired in a cross-sectional study of patients with aldosterone-producing adenomas, although this correlated with altered serum potassium [45]. More recently, Mosso et al. applied HOMA-2 to a group of patients with primary aldosteronism and found evidence of impaired beta cell function compared with patients with essential hypertension that was independent of serum potassium [11].

Our data may have particular relevance to the use of MR antagonists in diabetic participants and to the ongoing development of aldosterone synthase inhibitors. Treatment with either spironolactone or eplerenone increases plasma aldosterone concentrations, regardless of whether an ACE inhibitor or ARB is co-administered [46]. Glycaemic 
control worsened during spironolactone treatment in a randomised, placebo-controlled study in diabetic participants [47]. An additional observational study detected an increased incidence of diabetes in spironolactone-treated patients compared with losartan-treated patients [48]. The observation that aldosterone decreases insulin secretion through an MR-independent mechanism may explain these findings [47, 49], and further studies investigating this effect are warranted. During long-term ACE inhibitor or ARB administration, aldosterone increases back to baseline values, despite an initial suppression. Pharmacological agents that specifically target aldosterone synthase reduce plasma aldosterone in humans and could provide a therapeutic alternative in the future [50].

Acknowledgements The authors gratefully acknowledge the excellent technical assistance of T. Ansari and C. Malabanan. We thank A. Golovin at the Vanderbilt University Islet Procurement and Analysis Core for performing islet isolation and assessing islet insulin secretion. We thank the Vanderbilt University Hormone Assay Core for performing insulin assays. We also thank C. Gomez-Sanchez for generously providing antiMR antibodies. This work was supported by the Juvenile Diabetes Research Foundation International, the VA Research Service, the NIH (DK081662, DK66636, DK69603, DK68854, HL067308, HL060906, HL07738, DK072473, DK089572), the Vanderbilt Mouse Metabolic Phenotyping Center (DK59637) and the Vanderbilt Diabetes Research and Training Center (DK20593).

Duality of interest The authors declare that there is no duality of interest associated with this manuscript.

\section{References}

1. Rocha R, Stier CT Jr, Kifor I et al (2000) Aldosterone: a mediator of myocardial necrosis and renal arteriopathy. Endocrinology 141:3871-3878

2. Goodfriend TL, Egan BM, Kelley DE (1999) Plasma aldosterone, plasma lipoproteins, obesity and insulin resistance in humans. Prostaglandins Leukot Essent Fatty Acids 60:401-405

3. Bochud M, Nussberger J, Bovet P et al (2006) Plasma aldosterone is independently associated with the metabolic syndrome. Hypertension 48:239-245

4. Ingelsson E, Pencina MJ, Tofler GH et al (2007) Multimarker approach to evaluate the incidence of the metabolic syndrome and longitudinal changes in metabolic risk factors: the Framingham Offspring Study. Circulation 116:984-992

5. Tuck ML, Sowers J, Dornfeld L, Kledzik G, Maxwell M (1981) The effect of weight reduction on blood pressure, plasma renin activity, and plasma aldosterone levels in obese patients. N Engl J Med 304:930-933

6. Goodfriend TL, Ball DL, Egan BM, Campbell WB, Nithipatikom K (2004) Epoxy-keto derivative of linoleic acid stimulates aldosterone secretion. Hypertension 43:358-363

7. Conn JW (1965) Hypertension, the potassium ion and impaired carbohydrate tolerance. N Engl J Med 273:1135-1143

8. Colussi G, Catena C, Lapenna R, Nadalini E, Chiuch A, Sechi LA (2007) Insulin resistance and hyperinsulinemia are related to plasma aldosterone levels in hypertensive patients. Diabetes Care $30: 2349-2354$
9. Catena C, Lapenna R, Baroselli S et al (2006) Insulin sensitivity in patients with primary aldosteronism: a follow-up study. J Clin Endocrinol Metab 91:3457-3463

10. Kahn SE, Hull RL, Utzschneider KM (2006) Mechanisms linking obesity to insulin resistance and type 2 diabetes. Nature 444:840 846

11. Mosso LM, Carvajal CA, Maiz A et al (2007) A possible association between primary aldosteronism and a lower $\beta$-cell function. J Hypertens 25:2125-2130

12. Bosch J, Yusuf S, Gerstein HC et al (2006) Effect of ramipril on the incidence of diabetes. N Engl J Med 355:1551-1562

13. McMurray JJ, Holman RR, Haffner SM et al (2010) Effect of valsartan on the incidence of diabetes and cardiovascular events. N Engl J Med 362:1477-1490

14. Makhanova N, Lee G, Takahashi N et al (2006) Kidney function in mice lacking aldosterone. Am J Physiol Renal Physiol 290: F61-F69

15. Luther JM, Wang Z, Ma J, Makhanova N, Kim HS, Brown NJ (2009) Endogenous aldosterone contributes to acute angiotensin IIstimulated plasminogen activator inhibitor-1 and preproendothelin-1 expression in heart but not aorta. Endocrinology 150:2229-2236

16. Lee G, Makhanova N, Caron K et al (2005) Homeostatic responses in the adrenal cortex to the absence of aldosterone in mice. Endocrinology 146:2650-2656

17. Ayala JE, Bracy DP, McGuinness OP, Wasserman DH (2006) Considerations in the design of hyperinsulinemic-euglycemic clamps in the conscious mouse. Diabetes 55:390-397

18. Fueger PT, Hess HS, Bracy DP et al (2004) Regulation of insulinstimulated muscle glucose uptake in the conscious mouse: role of glucose transport is dependent on glucose phosphorylation capacity. Endocrinology 145:4912-4916

19. Berglund ED, Li CY, Poffenberger G et al (2008) Glucose metabolism in vivo in four commonly used inbred mouse strains. Diabetes 57:1790-1799

20. Brissova M, Shiota M, Nicholson WE et al (2002) Reduction in pancreatic transcription factor PDX-1 impairs glucose-stimulated insulin secretion. J Biol Chem 277:11225-11232

21. Miyazaki J, Araki K, Yamato E et al (1990) Establishment of a pancreatic beta cell line that retains glucose-inducible insulin secretion: special reference to expression of glucose transporter isoforms. Endocrinology 127:126-132

22. Brown NJ (2003) Eplerenone: cardiovascular protection. Circulation 107:2512-2518

23. Garthwaite SM, McMahon EG (2004) The evolution of aldosterone antagonists. Mol Cell Endocrinol 217:27-31

24. Gomez-Sanchez CE, de Rodriguez AF, Romero DG et al (2006) Development of a panel of monoclonal antibodies against the mineralocorticoid receptor. Endocrinology 147:1343-1348

25. Uehara S, Tsuchida M, Kanno T, Sasaki M, Nishikibe $M$, Fukamizu A (2003) Late-onset obesity in mice transgenic for the human renin gene. Int J Mol Med 11:723-727

26. Gratze P, Boschmann M, Dechend R et al (2009) Energy metabolism in human renin-gene transgenic rats: does renin contribute to obesity? Hypertension 53:516-523

27. Hitomi H, Kiyomoto H, Nishiyama A et al (2007) Aldosterone suppresses insulin signaling via the downregulation of insulin receptor substrate-1 in vascular smooth muscle cells. Hypertension 50:750-755

28. Lastra G, Whaley-Connell A, Manrique C et al (2008) Low-dose spironolactone reduces reactive oxygen species generation and improves insulin-stimulated glucose transport in skeletal muscle in the TG(mRen2)27 rat. Am J Physiol Endocrinol Metab 295:E110 E116

29. Carlsson PO, Berne C, Jansson L (1998) Angiotensin II and the endocrine pancreas: effects on islet blood flow and insulin secretion in rats. Diabetologia 41:127-133 
30. Leung PS, Chan WP, Wong TP, Sernia C (1999) Expression and localization of the renin-angiotensin system in the rat pancreas. $\mathrm{J}$ Endocrinol 160:13-19

31. Scheen AJ (2004) Prevention of type 2 diabetes mellitus through inhibition of the renin-angiotensin system. Drugs 64:2537-2565

32. Sindelka G, Widimsky J, Haas T, Prazny M, Hilgertova J, Skrha J (2000) Insulin action in primary hyperaldosteronism before and after surgical or pharmacological treatment. Exp Clin Endocrinol Diabetes 108:21-25

33. Voiculescu A, Hollenbeck M, Kutkuhn B, Grabensee B, Plum J (2003) Successful treatment of renovascular hypertension has no effect on insulin sensitivity. Eur J Clin Investig 33:848854

34. Festa A, Williams K, Hanley AJ, Haffner SM (2008) Beta-cell dysfunction in subjects with impaired glucose tolerance and early type 2 diabetes: comparison of surrogate markers with first-phase insulin secretion from an intravenous glucose tolerance test. Diabetes 57:1638-1644

35. Pierluissi J, Navas FO, Ashcroft SJ (1986) Effect of adrenal steroids on insulin release from cultured rat islets of Langerhans. Diabetologia 29:119-121

36. Chuang JC, Cha JY, Garmey JC, Mirmira RG, Repa JJ (2008) Research resource: nuclear hormone receptor expression in the endocrine pancreas. Mol Endocrinol 22:2353-2363

37. Lemarie CA, Simeone SM, Nikonova A et al (2009) Aldosteroneinduced activation of signaling pathways requires activity of angiotensin type 1a receptors. Circ Res 105:852-859

38. Boldyreff B, Wehling M (2003) Non-genomic actions of aldosterone: mechanisms and consequences in kidney cells. Nephrol Dial Transplant 18:1693-1695

39. Hirasawa G, Sasano H, Ki T et al (1997) Colocalization of $11 \beta$ hydroxysteroid dehydrogenase type II and mineralocorticoid receptor in human epithelia. J Clin Endocrinol Metab 82:3859-3863
40. Losel R, Schultz A, Boldyreff B, Wehling M (2004) Rapid effects of aldosterone on vascular cells: clinical implications. Steroids 69:575-578

41. Gekle M, Grossmann C (2009) Actions of aldosterone in the cardiovascular system: the good, the bad, and the ugly? Pflugers Arch 458:231-246

42. Briet M, Schiffrin EL (2010) Aldosterone: effects on the kidney and cardiovascular system. Nat Rev Nephrol 6:261-273

43. Drews G, Krippeit-Drews P, Dufer M (2010) Oxidative stress and beta-cell dysfunction. Pflugers Arch 460:703-718

44. Caprio M, Feve B, Claes A, Viengchareun S, Lombes M, Zennaro MC (2007) Pivotal role of the mineralocorticoid receptor in corticosteroid-induced adipogenesis. FASEB J 21:2185-2194

45. Shimamoto K, Shiiki M, Ise T et al (1994) Does insulin resistance participate in an impaired glucose tolerance in primary aldosteronism? J Hum Hypertens 8:755-759

46. Weinberger MH, White WB, Ruilope LM et al (2005) Effects of eplerenone vs losartan in patients with low-renin hypertension. Am Heart J 150:426-433

47. Swaminathan K, Davies J, George J, Rajendra NS, Morris AD, Struthers AD (2008) Spironolactone for poorly controlled hypertension in type 2 diabetes: conflicting effects on blood pressure, endothelial function, glycaemic control and hormonal profiles. Diabetologia 51:762-768

48. Arase Y, Suzuki F, Suzuki Y et al (2009) Losartan reduces the onset of type 2 diabetes in hypertensive Japanese patients with chronic hepatitis C. J Med Virol 81:1584-1590

49. Strauch B, Widimsky J, Sindelka G, Skrha J (2003) Does the treatment of primary hyperaldosteronism influence glucose tolerance? Physiol Res 52:503-506

50. Amar L, Azizi M, Menard J, Peyrard S, Watson C, Plouin PF (2010) Aldosterone synthase inhibition with LCI699: a proof-ofconcept study in patients with primary aldosteronism. Hypertension 56:831-838 